\section{0}

15
Working Paper

INSTHUTO DE POLITIGAS Y BIENES PÚBLIGOS [IPP]
LUIS MORENo

CONSEJO SUPERIOR DE INVESTIGACIONES CiENTÍFICAS (CSIC)

Institute of Public Goods And Policies (IPP) 


\section{INSTITUTO DE POLÍTICAS Y BIENES PÚBLICOS, CCHS-CSIC}

Copyright $(02010$. Moreno, L.. All Rights reserved.

Do not quote or cite without permission from the author.

Instituto de Políticas y Bienes Públicos

Centro de Ciencias Humanas y Sociales

Consejo Superior de Investigaciones Científicas

C/ Albasanz, 26-28.

28037 Madrid (España)

Tel: +34916022300

Fax: +34 913045710

http://www.ipp.csic.es/

The working papers are produced by Spanish National Research Council - Institute of Public Goods and Policies and are to be circulated for discussion purposes only. Their contents should be considered to be preliminary. The papers are expected to be published in due course, in a revised form and should not be quoted without the authors' permission.

\section{How to quote or cite this document:}

Moreno, L. (2010). Welfare Mix, CSR and Social Citizenship. Instituto de Políticas y Bienes Públicos (IPP), CCHS-CSIC, Working Paper, Number 5.

Available: http: hdl.handle.net/10261/24406 


\title{
WELFARE MIX, CSR AND SOCIAL CITIZENSHIP
}

\author{
LUIS MORENO \\ CONSEJO SUPERIOR DE INVESTIGACIONES CiENTÍFICAS (CSIC) \\ INSTITUTE OF PUblic GoOdS AND POLICIES (IPP-CCHS) \\ LUIS.MORENO@CCHS.CSIC.ES
}

A version of this paper has been published in International Journal of Sociology and Social Policy, Vol. 30, No. 11/12: 683-696

\begin{abstract}
Corporate Social Responsibility (CSR) is an important undertaking by corporations in order to advance social citizenship. In the last decades a growing implication of businesses and NGOs in welfare development has run hand in hand with a noticeable increase of both: (a) the for-profit welfare provision of policies and services to the general public, and (b) those programmes made available by corporations to their employees. All these developments, together with the provision of social policies by governments, have coalesced into a welfare mix of entitlements, interventions and policy instruments with long-term effects for the improvement of citizens' living conditions. In this paper an analysis of the worlds of welfare capitalism is contrasted with a CSR typology of policy governance within the context of the European Union. Considerations are made on the impacts that both the global order and the new social risks (NSR) have for the promotion of CSR and the advancement of social citizenship. A brief review of the case for the reconciliation of work and family life seeks to illustrate how CSR might induce a greater role for businesses in welfare systems. In the final section, proposals and hypotheses are put forward for future research endeavours.
\end{abstract}

\section{CONTENTS}

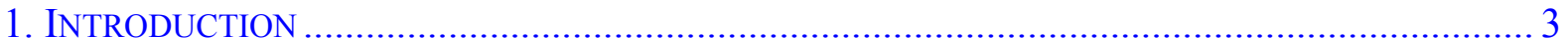

2. THE WORLDS OF WELFARE CAPITALISM AND CSR MODELS OF POLICY GOVERNANCE .......... 5

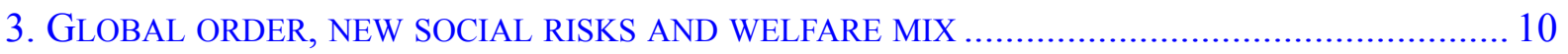

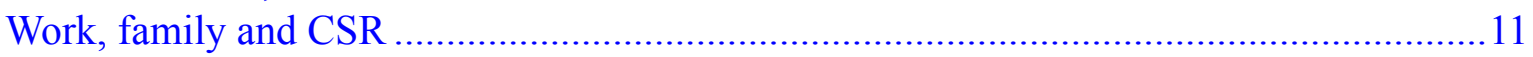

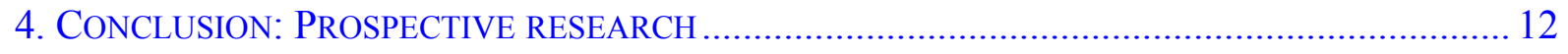

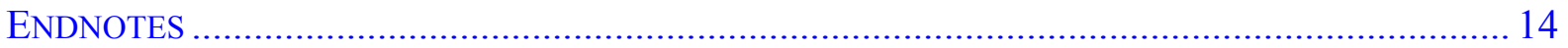

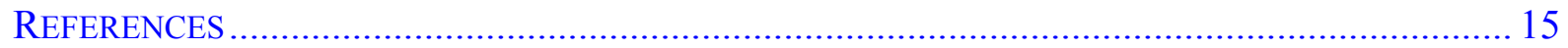




\section{INTRODUCTION}

The term "corporate responsibility" deals with a wide range of issues concerning the private sector. The label "social" is added in reference to the operations of companies and business in their relations with society. In concrete, Corporate Social Responsibility (CSR) may be defined as a concept whereby private corporations integrate social and environmental concerns in their interaction with their stakeholders, in particular, and with society, in general, on a voluntary basis (European Commission, 2001; 2002; 2006)

Neo-liberal views consider that CSR is incongruent with capitalism and that the social responsibility of businesses is to increase its profits (Friedman, 1970). Alternatively, CSR is said to be good for society and good for business (Emerald; Mattila, 2006). Indeed, the question on how the pursuit for corporations' profits can be coupled with citizens' general well-being is central to the very concept of CSR. In recent years the academic debate of CSR has increased notably among scholars from different disciplines and areas of study.

This paper elaborates on the idea that CSR, as an input to the contemporary welfare mix, may induce social policy development. Most analytical and research categories used in this paper are drawn from the academic fields of political economy, policy analysis and sociology with regard to the study of welfare capitalism and the implementation of CSR. It concentrates on social citizenship, a cornerstone in the modernity sequence of nation-building, state formation, mass democratization and welfare development, following Stein Rokkan's conceptualizations (Flora et al., 1999).[1] Indeed, the consolidation of Marshall's third cycle of social citizenship[2] was regarded to be achieved in the fourth phase of the system-building of Europe. This is in the process of institutional structuring and territorial adjustment within multi-layered EU (Bartolini, 2005). More than half of the legislation affecting Europeans' lives is already EU's. As a political framework, the European Union is a compound of policy processes, which go beyond the formal sovereignty of the member states (Piattoni, 2007).

However, the "state formation" of the United States of Europe cannot be envisaged as the necessary end-result of Europeanization. The neo-functionalist school of thought has generally adopted the view that universal progress requires integration, which is made equal to cultural assimilation and to over-reaching identity formation, along the lines of the American "meltingpot", or the multicultural "salad bowl". Alternatively, the establishment of common European rules may be accommodated by taking into account both long-standing history and cultural diversity within the mosaic of peoples in the Old Continent (Ferrera, 2005).

The advancement of social citizenship is regarded as a desideratum not just for the needy or excluded groups, but as a societal shared goal. It complements other civil and political components of citizenship. The latter is conceptualized as a compound of practices and uses that confer the quality of active members to free individuals within their political communities of reference (Janoski, 1998; Roche, 1992, 2002; Isin, 2008). 
As corporate citizens, a greater involvement of companies is regarded as desirable for the expansion of social rights (Moon, 2002; Matten and Crane, 2003; Matten, Crane and Moon, 2009). It is generally assumed that a strong sense of business responsibility towards local communities, by means of formalizing partnerships, together with respect for the environment, is an important aspect of CSR. This is also assessed as optimal in providing the strategic means for: (a) optimising business strategies by improving and promoting the public image of corporations; and (b) legitimizing responsible market competition based upon the assumption that the wellbeing of business depends on the well-being of society (Garriga and Melé, 2004).

In advanced industrial societies, welfare development has mainly relied on government's provision of public policies for citizens (e.g. formal instruction, health provision, income support, or care services). Welfare has also been implemented with the aim of achieving economic growth (by means of macro-economic agreements among the social partners or through economic policies of income distribution). An overriding attention in the analyses of contemporary welfare states has usually been geared towards the "autonomous" action of state public intervention in providing security to its citizens. The fact that the welfare state action has made concordant with modernity many functions which had been previously developed by families, churches, guilds, corporations, NGOs or local communities has often been ignored (Flora and Alber, 1981).

At the turn of the second millennium, social citizenship has remained a legitimate goal in contemporary societies. Welfare producers and consumers have nevertheless had to adapt their roles and functions to the changing scenarios brought about by the new global order and the irruption of the "new social risks" (NSR). The latter are associated mainly with societal changes in the family and the labour market and shifts from bureaucracy to post-bureaucracy, informal to formal work, non-commodified to commodified work, or Fordism to post-Fordism in a globalized world (Esping-Andersen et al., 2002; Williams, 2007).

The crisis of the "command-and-control" efforts by the central state to develop uniform statewide social services and national institutions has been confused with a crisis tout court of the welfare state model. In fact, the politics and policies of social welfare continue to be highly supported by the population at large (Svallfors and Taylor-Gooby, 1999; Bonoli, 2000; Kuhnle, 2000; Pierson, 2001; van Oorschot, 2002; ESS, 2008).The role of governments in avoiding social unrest and preserving economic and social stability in the aftermath of the 2007 financial crisis has been crucial. In many instances state intervention has come to rescue irresponsible corporations--mostly financial-- and to sort out consequences that could have provoked an economic recession with potential devastating effects for the well-being of individuals worldwide. 
Despite its "traditional" function as provider of public policies and as gamekeeper of social peace, the welfare state is facing new challenges to assume new forms of governance at local, national and global levels. In fact, both processes of trans-nationalization and subsidiarization have put limits to the state-centric implementation of welfare development. The growth to limits, or maturation of public welfare policies covering "old" social risks (e.g. illiteracy, old-age, sickness or unemployment), has brought to the fore new proposals for articulating a privatepublic welfare mix as the best means for the procurement of people's well-being and, thus, for providing social benefits and services covering NSR.

This paper reflects on those "meeting points" and "encountering places" where the action of individuals, families, corporations. NGOs and public policies can optimize the advancement of social citizenship. The context of analyses is that provided by developments in Europe, the Continent where the welfare state was "invented". CSR serves as the main argumentative thread to contribute with critiques, ideas a proposals to the conceptualizations made in this paper.

In the following section an analysis of the worlds of welfare capitalism is contrasted with a CSR typology. Such an exercise serves the purpose of highlighting not only institutional arrangements and operational welfare rationales, but also value-systems and cultural tenets shaping commonalities and diversities in public policy governance in the European Union. Subsequently, considerations are made on the impacts that the global order and the emergence of NSR have for the promotion of CSR and social citizenship. A succinct examination of the case for the reconciliation of work and family life illustrate how CSR might induce a greater role for businesses in welfare systems. Final remarks points out to prescriptions, proposals and hypotheses for prospective research.

\section{The WORLDS OF Welfare CAPITAlisM AND CSR MODELS OF POLICY GOVERNANCE}

During the trentes glorieuses, or Golden Age of welfare capitalism (1945-75), West European systems of social protection were based upon the assumption of full employment and --implicitly-on the complementary role of the family, and, in particular, of women's unpaid work within households (Lewis, 1997). A combination of social policies, Keynesianism, Taylorism and female segregation facilitated a sustained economic growth and the generalisation of a type of "affluent worker" (Lipset, 1960). The outcome of these factors translated into two main types of welfare state: the Keynes-Beveridge and the Keynes-Bismarck welfare state. In both cases governments managed economies with a relatively high degree of autonomy. They were able to provide social provision for needs which market and family did not meet. The tax consequences of such provision were legitimated upon political coalitions of working and middle class groups (Flora, 1986/87). 
The effects of the oil crises in 1973-74 and 1978-79 revealed the increasing openness and interdependence of the developed economies, and altered a scenario of prosperity and abundant stable male employment in the Western hemisphere. Nevertheless, the European Golden Age evolved into a Silver Age of the welfare state showing limitations but also a high degree of resilience in resisting pressures of a diverse nature (Taylor-Gooby, 2002). During the 1980s and 1990s, a neo-liberal ideological offensive challenged the tenets and legitimacy upon which welfare states had previously developed. Fiscal crises and the erosion of the ideological consensus which gave way to a "mid-century compromise" (Crouch, 1999) conditioned the subsequent recasting of welfare states in Europe (Ferrera and Rhodes, 2000).

For the study of the evolution and features of the various types of welfare states the regime approach has proved to be very persuasive in linking together a wide range of elements considered to influence welfare development and outcomes. The regime approach put forward the idea that clusters of countries are characterised by a particular constellation of economic, political and social arrangements. According to this line of analysis, such families of nations or welfare regimes are structured around one particular organising principle, ideological underpinning or cultural commonality adding up to a welfare "logic". Individual empowerment (Liberal Anglo-Saxon), statist egalitarianism (Social-Democratic Nordic) or institutional partnership (Corporatist Continental) could be singled out as core "rationales" in the cases of the well-known and well-researched three worlds of welfare capitalism (Esping-Andersen, 1990; 1999).

An assumption of continuity tends to prevail over that of change, in establishing patterns of interaction according to the regime approach. As a consequence, it is implicitly assumed that a particular welfare state will tend to sustain interests and arrangements identified within the three main categories. Institutional inertia and "sunk costs" for the covering of "old" social risks usually translate in prescriptions of path dependency (historical and self-reinforcing). As a result, welfare states are regarded as a sort of "immovable objects" (Pierson, 1998). The historical new institutionalism school of thought has provided plausible explanations on the nature and scope of welfare reforms and has been very influential in the spelling out of the regime approach. However, it has been criticized for having found difficulties in integrating societal changes into its main analytical framework (Janoski, 1998; Roche, 2002; Bambra, 2006).

The welfare regime approach has also been received feminist critiques as it has tended to assume women's unpaid work within households as a "given fact". In fact, the role of women as carers of children and elderly has been paramount in sustaining institutional arrangements in all welfare regimes, and specially in those which have relied more heavily in the subsidiarity role of families (Continental and Mediterranean, principally). De-commodification, a widely-used analytical tool of the regime approach has often failed to understand the crucial importance of unpaid work (Lewis, 1992; Orloff, 1996; Williams, 2002). There is a progressive generalisation 
of the 'dual-earner' model in all welfare regimes. However, there is no consensus from a feminist perspective as what should be the optimal course of action in order to favour gender equality within households. Beyond the desirability of an external "de-familization" of women's unpaid caring work, there remains the question on whether such proposals do little more than disguising the unequal relations of power within households.

In general terms, and within the context of the European Union, [3] four types of welfare regimes may be described briefly as follows:

The corporatist Continental regime is organized on the basis of occupational categories and is designed much less to reduce inequality than to maintain status. It is characterised by concerted action between employers and trade unions, and is financed by the contributions they make. Welfare policies by state institutions uphold this arrangement, which is organised through social insurance. There is a sharp distinction between labour market "insiders" and "outsiders". The universality of coverage is therefore dependent on the achievement and maintenance of full employment.

The liberal Anglo-Saxon regime was initially patterned by its commitment to a form of universality in the case of the UK (Beveridge Report). Focused on poverty alleviation it is financed by taxes and incorporates residual means-tested services and flat-rate benefits. It has pursued a radical shift toward market principles, involving deregulation of the labour market, wage flexibility and retrenchment in social expenditure. A low level of de-commodification of individuals implies a large measure of dependence by citizens on the market to ensure their primary income and social protection.

The social-democratic Nordic regime is premised on the combination of solidaristic ideas with growth and full employment, and the minimisation of family dependence. It is financed by taxes, characterised by the principle of universality, and favours the public provision of free services rather than cash transfers. The main aim of this type of welfare state is to ensure the equality and homogeneity of social groups within an all-embracing middle class. Full employment is a goal based on broad political compromises and consensual governance.

The familialistic Mediterranean regime is characterised by the central role played by the family and its interpenetration in all areas of welfare production and distribution. [4] This results in a strong household micro-solidarity and other solidarity networks. Southern welfare has performed as a via media in trying to integrate citizenship programmes (social assistance, noncontributory pensions), occupational benefits and services (family dependent entitlements, labour-related benefits), or even universal schemes (education, health care).

These four types of welfare regimes associate a specific institutional configuration with a founding culture, doctrine and value-system: (1) Social insurance schemes with the protection of specific occupational categories (Continental); (2) Residual benefits with the primacy of the market and the need to combat poverty (Anglo-Saxon); (3) Universal benefits with the quest for equality (Nordic); and (4) Complementarity in the interaction among family, public bodies and 
civil society (Mediterranean). Such tenets have coalesced into distinctive rationales shaping the varieties of contemporary capitalism and having a different impact in terms of the quality of social rights, social structures and the structure of productive markets (Hall and Soskice, 2001) (Table 1 reproduces a compendium of some characteristic features European welfare regimes).

A look at how CSR governance polices align, or otherwise, with the welfare regime taxonomy is useful to identify those "meeting points" around which social citizenship could be enhanced. The contrast between general welfare regimes and mainstream business approaches is useful for the identification of those "encountering places" where a more effective combination of the public and the private can result in effective synergies within the welfare mix.

Schemes of voluntary work, tax breaks or occupational/corporate welfare --to name just a few-- can be regarded as important inputs to the general well-being of citizens. However, they are not usually taken into account for the calculation of net social spending.[5] Employers and corporations may not only perform a role as "gatekeepers" for social protection, but can also develop important roles for the implementation of innovative programmes covering NSR (initiatives for the reconciliation of work and family life are discussed further below).This combination of CSR policies, welfare structures and individual responsibilities is regarded as facilitating a plausible scenario for the advancement of social citizenship (Glazer, 1988; Alber, 2006).

A four CSR typology has been proposed concerning the roles played by public and private actors, legal frameworks, incentives, governance structures and the ways all of these evolve. The classification takes a relational approach in which the development of cross-sector proposals (dialogues, partnerships and networks) is regarded as a decisive aim of CSR. As a result, four European models of public policy governance fostering CSR have been identified: Sustainability, Business in the Community, Partnership and Agora (Alboreda et al., 2008):

(1) The Sustainability model applied by central Continental countries underlines the concerns for sustainable development strategies. CSR as a concept may be regarded as not being itself a main axis. France takes a most regulatory approach to CSR in tune with long-standing values of centralized legislation. Other countries, like federal Austria, Belgium or Germany, seek to incorporate local and regional inputs and allow for certain asymmetries in CSR regulation in line with a more open model of intergovernmental relations. 
Table 1: Features of the European Welfare Regimes

\begin{tabular}{|c|c|c|c|c|}
\hline & Anglo-Saxon & Continental & Nordic & Mediterranean \\
\hline Benefits & $\begin{array}{c}\text { Flat rate (low inten- } \\
\text { sity) }\end{array}$ & $\begin{array}{c}\text { Cash (high inten- } \\
\text { sity) }\end{array}$ & $\begin{array}{c}\text { Flat rate (high } \\
\text { intensity) }\end{array}$ & Cash (low intensity) \\
\hline Financing & Taxes & $\begin{array}{c}\text { Payroll contribu- } \\
\text { tions }\end{array}$ & Taxes & Mixed \\
\hline Gender & Female polarization & $\begin{array}{c}\text { Part-time femini- } \\
\text { zation }\end{array}$ & Occupational spe- & Ambivalent fami- \\
cific & lialism \\
\hline Goals & Individual choice & $\begin{array}{c}\text { Income mainte- } \\
\text { nance }\end{array}$ & Network public & Resource optimi- \\
services & zation \\
\hline Ideology & Citizenship & Neo-corporatism & Egalitarianism & Social justice \\
\hline \multirow{2}{*}{ Labour Market } & De-regulation & Insiders/outsiders & $\begin{array}{c}\text { High public emplo- } \\
\text { yment }\end{array}$ & $\begin{array}{c}\text { Big informal eco- } \\
\text { nomy }\end{array}$ \\
\hline Poverty & Dependency culture & Insertion culture & Statist culture & Assistance culture \\
\hline Services & Residual public & Social partners & Comprehensive & Family support \\
\hline CSR & Business in the & Sustainability & Partnership & Agora-type \\
\hline
\end{tabular}

(2) The Business in the community model relates to the United Kingdom and Ireland. Government is seen as a facilitator or mediator in tune with a more liberal and less normative view. These countries pursue the solution of social problems like unemployment and social exclusion through CSR policies: companies can get involved and can develop a more active role in providing corporate welfare. Government has based its application of CSR on soft law.

(3) The Partnership approach towards CSR includes the Nordic countries plus the Netherlands. These countries, particularly the Scandinavia, have matured generous welfare states, and relationships between public administrations and companies develop in a general climate of cooperation. Local governments are heavily involved in channelling the formation of partnerships that encourage the concept of social co-responsibility between administrations, companies and social organizations.

(4) The Agora typology applies to EU's Southern European countries such as Italy, Spain, Portugal and Greece, all of which addressed CSR after the European Commission initiative was taken in 2001. Some CSR policies have been implemented following the drafting of a considerable degree of reports and studies analysing the development of CSR, and encouraging governmental action. Debates often express a general positive attitude towards CSR and seek to achieve resource optimisation in line with a multiplicity of agora-type inputs from both public bodies and civil society..

These four European models of public policy governance fostering CSR articulate themselves which each and of the four welfare regimes examined earlier. Indeed, both taxonomies have plenty of interconnections and "meeting points" and both respond to similar concerns and 
trajectories: (A) Corporatist Continental - Sustainability; (B) Liberal Anglo-Saxon - Business in the Community; (C) Social-democratic / Partnership; and (D) Familialistic Mediterranean / Agora. On conceptualizing the future development of the European socio-economic model, further comparative research is needed, so that the identification of common features from both sets of typologies would form a base-line of comparison. Otherwise, and as has been the case in most cross-national exercises in recent decades, the absence of an overarching point of reference is most likely to result in the continuation of ethnocentric comparative research.[6]

\section{GLOBAL ORDER, NEW SOCIAL RISKS AND WELFARE MIX}

The globalisation and internationalisation of trade--encouraged mainly by the telecommunication innovations during the 1990s onwards-- have decisively affected the economy world-wide, and have brought about a deep restructuring of contemporary capitalism. Likewise, financial globalisation has meant a transfer of authority and power from the nation-states to supranational markets. The very pattern of economic competition has been meant to comply with the standards of global markets and the strategies of transnational corporations (Jones, 1995; Kilminster, 1997; Hirst and Thompson, 1999).

In the midst of fiscal crises of the 1980s and 1990s, the erosion of the post-war ideological consensus gave way to an increasingly unstable compromise between capitalism and welfare.[7] The new economic neo-classical and supply-side paradigm, along the lines of a Schumpetarian workfare state, which regards "unrestricted" market freedom as essential to economic success, aimed at strengthening the competitiveness of national economies and at subordinating welfare policy to the demands of flexibility (Jessop, 1994). In Europe as in the US the word "activation" has become a key word for welfare reform in line with the idea of the "enabling state" (Gilbert, 2002; Moreno and Palier, 2005).

Within the European context, changes and policy reforms were justified by most governments as required in order to meet the 1992 Maastricht criteria to achieve the economic and monetary union (EMU). In this way, political, EU's social and economic dynamics were integrated into domestic political discourses and public policies, making it evident that the process of welfare reforms were, at least partially, Europeanised (Scharpf, 1996).

The blame avoidance argument claims that globalization inevitably leads to a reduction of social rights. This should be qualified. Indeed, social and environmental standards, particularly in less developed countries, can be highly shaped by foreign direct investments decisions taken by company boards of the basis of short-term interests, or in the expectations of immediate returns. This might induce local or national governments to offer incentives of lower salaries and social welfare. But there cases where the contrary happens. Both politicians and decision-makers at state and sub-state levels may become "credit-claimers", instead of or "blame-avoiders", depending upon their situational logic and political strategies: what is economically efficient 
may not be politically possible or sustainable. Thus, political impacts on national and regional bureaucracies in the implementation process must be taken into account. Likewise, national and regional politicians seek credit for their activities and they do so regardless of economic and rational arguments (Moreno and McEwen, 2005).

All things considered, the processes of globalization of the economy and industrial transformations have had wide-range effects on the national markets around the world. There have also been deep structural modifications in advanced industrial democracies as a consequence of the emergence of new social risks (NSR). These are associated with the transition to a post-industrial (postFordist) society, and include four main elements: (1) higher participation of women in the formal labour market; (2) an increase in the numbers of frail and dependent elderly people; (3) the rise of social exclusion for workers with poor education; and (4) the expansion of irresponsible private services and the de-regulation of their public counterparts (Taylor-Gooby, 2004).

As a consequence, vulnerable groups are likely to experience new needs in three broad areas: (i) balancing paid work and family responsibilities (especially child-care), (ii) being called on for care for a frail elderly relative, or becoming frail and lacking family support; (iii) lacking the skills necessary to gain access to an adequately paid and secure job, or having skills and training that become obsolete and being unable to upgrade them through life-long learning; and (iv) using private provision that supplies an insecure or inadequate pension or unsatisfactory services (Bonoli, 2005).

The answer to the question of whether NSR would induce new welfare re-arrangements and how they could be reconciled with old core commitments for social provision is still to be articulated by the multiple actors involved in the various contexts of European governance. Until now, NSR do not seem to add up to a new paradigm of welfare, but ought rather to be regarded as a policy adaptation which will generate new political discourses in Europe after the inception of the 2009 Treaty of Lisbon [8]. The very nature of the multi-tiered and multi-level governance model in Europe makes most relevant the expansion of corporate welfare for the covering of NSR. Beyond the recourse to public subsidies for the hiring of workers, particularly in times of deep economic crisis, fiscal incentives to companies can also be important for the input of corporate welfare. In situations where the interaction between employers and employees is crucial to respond to NSR, the production of social citizenship rights is highly dependent on articulating arrangements for the optimal articulation of the welfare mix.

\section{Work, family and CSR}

The case for the reconciliation of work and family responsibilities illustrate how those "meeting points" between welfare and CSR can advance social citizenship and optimize business activities. Women's participation in the "formal" labour market makes the "compatibilization" of domestic and paid work all the more difficult. Among other factors, the decline of fertility rates can be correlated with the steady increase in female labour participation, particularly in 
those European countries which have gradually left behind the traditional male-breadwinner family model. In some countries, the transition to a fully 'dual-earner' model has moved in the direction of a "hybrid regime". This combines one model in which well-being and care is provided by families --namely, women--, while men assume "breadwinning" responsibilities, and a second one in which both women and men provide care and employment--with the help of governmental parental leave benefits and an increase of childcare services. In those countries, where public family policies are less generous, the main family strategy of working mothers is to count on 'substitute mothers', usually a family or kin member living nearby.

Through agreements between employers and employees at plant and occupational levels --which eventually might benchmark practices at regional and national level-- businesses can effectively contribute not only to greater gender equality in European societies, but to making effective the activation of productive resources by means of increasing women's participation in the formal labour market (EFILWC, 2006). Among those agreements to be worked out by stakeholders and social actors the following can be identified as having a great potential for development:

(a) Flexibilization of working hours for parents according to business planning and production requirements. Encouragement of work-from-home employment, when the nature of the industrial activities allows to carrying out activities and professional duties telematically.

(b) Establishment of codes of 'good practices' for female employees, with the legal endorsement of 'null and void' dismissals for pregnant, new mothers or users of family leave arrangements.

(c) Introduction of family-care leave schemes. Implementation of existing unpaid parental leaves (for both parents) and reduced-working time entitlements to take care of relatives needing care due to severe illness, accident or old age.

(d) Adoption of concerted child-care schemes with the public authorities at workplaces. This would be coupled with the integration of the education period of $0-3$ year-old children into the formal national instruction systems.

(e) Application of tax breaks and the reduction of payroll contributions to those corporations implementing the agreements reached between employers and employees for the optimization of work-family initiatives.

\section{Conclusion: Prospective RESEARCH}

"Meeting points" and "encountering places" in the analysis of CSR and social citizenship are worth devoting research efforts in the future. The relationship between the welfare regime approach and the models of public policy supports for CSR ought to be grounded on more systematic linkages between the two of them. The following prescriptions, proposals and hypotheses can provide some areas of interest for prospective research endeavours: 
(1) The promotion of CSR may induce the optimisation of the welfare mix in the advanced industrial welfare democracies. The regulatory role of public bodies is to incorporate the inputs of corporations (private and public), NGOs and other civil society groups. In particular, initiatives and agreements between employers and employees --illustrated by the case for the reconciliation of work and family life-- may improve citizens' living conditions and optimize welfare development.

(2) CSR policies are to take on board past patterns of welfare arrangements at the level of EU's member states. But they may also incorporate common concerns for policy innovation according to a general model of European public policy governance --still in the making. CSR policies are also to internalize a framework of shared interests for the unfolding of EU's common axiological model of sustainable economic growth and social cohesion.

(3) As the exercise of authority across and within different jurisdictions, multi-level governance in the European Union rests upon the guiding principles of democratic accountability and territorial subsidiarity. Sub-state layers of government have found in these principles a renewed impulse for the running of public affairs. Intergovernmental co-operation is facing the challenge of adapting itself to a situation where national states are gradually less "sovereign" than they have been up until now.[9] In EU's context, "soft governance" initiatives such as the Open Method of Co-ordination (OMC), "best practices" and "benchmarking" could provide for mutual learning at both inter and intra levels of the member states.

The above prescriptions, proposals and hypotheses ought to be substantiated in prospective research projects. They may provide sounded evidence on the desirability for interconnecting CSR, welfare mix and social citizenship. From both ethical and practical grounds, CSR can be good for firms, individuals and polities, but such claims need to be further investigated. In all future scenarios, the advancement of social rights is as a common goal at stake shared by the citizenship at large in the permanent quest for a good society. 


\section{ENDNOTES}

1. Stein Rokkan (1921-79) drew attention on the interrelations between internal structuring and external boundary-building for understanding the connections between state formation (administrative and military), nation-building (cultural), and the development of mass democracies (political). Welfare development is the latter stage in Rokkan's attempt to put forward a typological-topological map of Europe.

2. This was viewed as the subsequent historical stage once political and civil citizenship had been realized (Marshall, 1950; 1965). Marshall's argument for social citizenship can be regarded as a dynamic account --rather than as an evolutionary theory-- of the struggle between the extension of political equality and social rights, on the one hand, and the capitalist market and social class, on the other hand (Breiner, 2006).

3. It has been argued whether Eastern Europe constitute a welfare regime on its own (Deacon, 2000). Recent trends seem to indicate that while some ex-Communist countries cluster around the 'liberal' typology, others are closer to the Bismarckian orientation (Potůček, 2008).

4. In all welfare regimes the family has a role to play. However, both central and northern Europe contexts, together with the USA, are characterized by having weak family links while the Mediterranean region has strong family ties. According to this view, differences have deep historical roots and are not diminishing at present in any fundamental manner (Reher, 1998).

5. The case of US exemplifies a welfare system that is less based on public and social assistance, and that could be labelled as corporatized social citizenship (Dobbin, 2002).

6. It comes as no surprise that welfare state studies have tended to be rather Nordic-centric and, in particular, Swedish-centric.

7. The 'O'Goffe's tale' makes reference to the theses put forward by O'Connor (1973), Gough (1979) and Offe (1984) that an insuperable contradiction for the maintenance of the solidaristic welfare state was due to both processes of legitimising the capitalist system and the erosion of the mechanisms of capitalist accumulation.

8. The Treaty of Lisbon entered into force on 1 December 2009 and is to be read in conjunction with other legally binding European documents, such as the "Treaty on European Union", the "Treaty establishing the European Community", and "EU's Charter of Fundamental Rights (see Final Act, 2007)

9. Those countries which attempted to exercise their nominal state sovereignty against the tide of the new economic policies were heavily penalised. Failure of the programmes for indicative planning implemented by the first Mitterrand Government in the early 1980s illustrated the 'persuasiveness' of the new economic neo-classical and supply-side paradigm embraced by neighbouring and competing countries. This episode illustrated that national economic 'sovereignty' was very limited in manoeuvres to promote the previous Keynesian demand-side approach (Camilleri and Falk, 1992; Schmidt, 1995; Strange, 1995). 


\section{REFERENCES}

1. Alber, J. (2006), "The European Social Model and the United States", European Union Politics, Vol. 7 No. 3 , pp. 393-419.

2. Alboreda, L.; Lozano, J. M. and Ysa, T. (2007), "Governance Strategy in Corporate Social Responsibility: Relational Approach and European Governments”, CSR Paper 29.2007, Fondazione Eni Enrico Mattei, Milan, available at: http://www.feem.it/NR/Feem/resources/CSRPapers/CSR2007-029.pdf. (accessed 29 December 2009).

3. Bambra, C. (2006), "Decommodification and the worlds of welfare revisited", Journal of European Social Policy, Vol 16 No 1: pp. 73-80.

4. Bartolini, S. (2005), Restructuring Europe: Centre formation, system building and political structuring between the nation-state and the European Union, Oxford University Press, Oxford.

5. Bonoli, G. (2000), "Public attitudes to social protection and political economy traditions in Western Europe", European Societies, Vol. 2 No. 4, pp. 431-453.

6. Bonoli, G. (2005), "The politics of the new social policies: Providing coverage against new social risks in mature welfare states', Policy and Politics, Vol. 33 No. 3, pp. 421-449.

7. Breiner, P. (2006), "Is Social Citizenship Really Outdated? T. H. Marshall Revisited", paper presented at the annual meeting of the Western Political Science Association, Albuquerque, NM, 17 March, 2006, available at: www.allacademic.com/meta/p97572_index.html (accessed 23 December 2009).

8. Camilleri, J. and Falk, J. (1992), End of Sovereignty? The Politics of a Shrinking and Fragmenting World, Edward Elgar, Aldershot.

9. Crouch, C. (1999), Social Change in Western Europe, Oxford University Press, Oxford.

10. Deacon, B. (2000), “Eastern European Welfare States: The Impact of the Politics of Globalisation”, Journal of European Social Policy, Vol 10 No 2, pp 121-146.

11. Dobbin, F. (2002), “Is America Becoming more Exceptional?”, in Rothstein, B. and Steinmo, S. (Eds.), Restructuring the Welfare State. Political institutions and Policy Change, Palgrave Macmillan, New York, NY, pp. 51-77.

12. Emerald, Corporate Social Responsibility at Emerald: good for business and good for society, available at http://info.emeraldinsight.com/about/pdf/csr.pdf (accessed 4 March, 2010).

13. ESS Round 4: European Social Survey Round 4 Data (2008). Data file edition 1.0. Norwegian Social Science Data Services, Norway - Data Archive and distributor of ESS data.

14. Esping-Andersen, G. (1990), The Three Worlds of Welfare Capitalism, Polity Press, Cambridge, UK.

15. Esping-Andersen, G. (1999), Social Foundations of Post-industrial Economies, Oxford University Press, Oxford.

16. Esping-Andersen, G. (with Gallie, D., Hemerijck A., and Myles, J.), 2002. Why We Need a New Welfare State, Oxford, Oxford University Press.

17. European Commission (2001), Green Paper: Promoting a European Framework for Corporate Social Responsibility, COM 366, Brussels.

18. European Commission (2002), Corporate Social Responsibility: A Business Contribution to Sustainable Development, COM 347, Brussels.

19. European Commission (2006), Implementing the Partnership for Growth and Jobs: Making Europe a pole of excellence on CSR, COM 136, Brussels.

20. EFILWC - European Foundation for the Improvement of Living and Working Conditions (2006), "Reconciliation of work and family life and collective bargaining in the European Union. An analysis of EIRO articles", available at http://www.eiro.eurofond.eu.int (accessed 29 December 2009).

21. Ferrera, M. (2005), The Boundaries of Welfare. European Integration and the New Spatial Politics of Social Protection. Oxford: Oxford University Press. 
22. Ferrera, M. and Rhodes, M. (Eds.) (2000), Recasting European Welfare States, Frank Cass, London.

23. Final Act - Treaty of Lisbon (2007), European Commission, Brussels, available at http://www.consilium. europa.eu/uedocs/cmsUpload/09-cg15.en7.doc (accessed 4 March, 2010).

24. Flora, P. (1986/87), “Introduction”, in Flora, P. (Ed.), Growth to Limits. The European Welfare States Since World War II (3 Vols.), De Gruyter, Berlin and New York, pp.XI-XXXVI.

25. Flora, P. and Alber, J. (1981), "Modernization, democratization and the development of welfare states in western Europe", in Flora, P. and Heidenheimer, A.J. (Eds.), The Development of Welfares States in Europe and America, Transaction Books, New Brunswick, N.J., pp.37-80.

26. Flora, P., Kuhnle, S. and Urwin, D. (Eds.) (1999), State Formation, Nation-Building and Mass Politics in Europe. The Theory of Stein Rokkan. Oxford University Press, Oxford.

27. Friedman, M. (1970), "The Social Responsibility of Business is to Increase its Profits", , 13 September, pp. 33/122-24, available at http:/graphics8.nytimes.com/packages/pdf/business/miltonfriedman1970.pdf (accessed 04 March 2010).

28. Garriga, E. and Melé, D. (2004), 'Corporate Responsibility: Mapping the Territory', Journal of Business Ethics, Vol. 53 Nos. 1-2, pp. 51-71.

29. Gilbert, N. (2002), Transformation of the Welfare State, Oxford University Press, Oxford.

30. Glazer, N. (1988), The Limits of Social Policy, Harvard University Press, Cambridge, MA.

31. Gough, I. (1979), The Political Economy of the Welfare State, Macmillan, London.

32. Hall, P. and Soskice, D. (2001), “An Introduction to Varieties of Capitalism”, in Hall, P. and Soskice, D. (Eds.), Varieties of Capitalism. The institutional Foundations of Comparative Advantage, Oxford University Press, Oxford, pp. 1-68.

33. Hirst, P. and Thompson, G. (1999) Globalization in Question, (2nd ed.), Polity Press, Cambridge, UK.

34. Isin, E.G. (Ed.) (2008), Recasting the Social in Citizenship University of Toronto Press, Toronto.

35. Janoski, T. (1998), Citizenship and Civil Society. A framework of Rights and Obligations in Liberal, Traditional, and Social Democratic Regimes, Cambridge University Press, Cambride, UK.

36. Jessop, B. (1994), “The transition to post-Fordism and the Schumpeterian workfare state", in Burrows, R. and Loader, B. (Eds.), Towards a Post-Fordist Welfare State?,. Routledge, London, pp. 13-37.

37. Jones, R. (1995), Globalization and Interdependence in the International Political Economy, Pinter Publishers, London.

38. Kilminster, R. (1997), "Globalization as an emergent concept”, in Scott, A. (Ed.), The Limits of Globalization, Routledge, London, pp.257-83.

39. Kuhnle, S. (Ed.) (2000), The Survival of the European Welfare State, Routledge, London.

40. Lewis, J. (1992), 'Gender and the Development of Welfare Regimes', Journal of European Social Policy, Vol. 2 No. 3, pp. 159-173.

41. Lewis, J. (1997), 'Gender and Welfare Regimes: Further Thoughts’, Social Politics, 4(2): 160-177.

42. Lipset, S.M. (1960), Political Man. The Social bases of politics, New York, Doubleday Anchor, New York, N.Y.

43. Marshall, T.H. (1950), Citizenship and Social Class and Other Essays. Cambridge: Cambridge University Press, Cambridge, UK.

44. Marshall, T. (1965). Social Policy in the Twentieth Century. London: Hutchinson.

45. Matten, D. and Crane, A. (2003), "Corporate Citizenship: Towards an extended theoretical conceptualization", No. 04-2003 ICCSR Research Paper Series, available at: http://www.nothingham.ac.uk/business/ICCSR/ (accessed 29 December 2009).

46. Matten, D., Crane, A. and Moon, J. (2009), "The corporation as a political actor: a citizenship perspective", Paper presented at the annual meeting of the WPSA annual meeting Ideas, Interests and Institutions, 19 March, 2009, available at http://www.allacademic.com/meta/p317271_index.html

47. Mattila, M. (2006), "Studying Corporate Social Responsibility in Finland: Genuine Gesture or Pursuit of a 
Big(ger) Profit?”, Social Responsibility Journal, Vol 2 No 2, pp. 159-164

48. Moon, J.(2002), "The Social Responsibility of Business and New Governance”, Government and Opposition, Vol.37 No.3, pp.385-408.

49. Moreno, L. and McEwen, N. (2005), "Exploring the territorial politics of welfare", in McEwen, N. and Moreno, L. (Eds.), The Territorial Politics of Welfare, Routledge, London pp. 1-40.

50. Moreno, L. and Palier, B. (2005), "The Europeanization of Welfare: Paradigm shifts and social policy reforms", in Taylor-Gooby, P. (Ed.), Ideas and Welfare State Reform in Western Europe, Palgrave Macmillan, London, pp. 145-175.

51. O’Connor, J. (1973), The Fiscal Crisis of the State, St Martin's Press, New York, NY.

52. Offe, C. (1984), Contradictions of the Welfare State, (John Keane, Ed.), Hutchinson, London.

53. Orloff, A. (1996), “Gender in the welfare state”, Annual Review of Sociology, Vol. 22 No. 1, pp 51-78.

54. Piattoni, S. (2007), “Governance Citizenship or Multi-Level Political Representation?”, in Foradori, P; Piattoni, S. and Scartezzini, R. (Eds.), European Citizenship: Theories, Arenas, Levels, Nomos Verlagsgeselschaft, Baden-Baden, pp. 167-175.

55. Pierson, P. (1998), "Irresistible forces, immovable objects: post-industrial welfare states confront permanent austerity", Journal of European Public Policy, Vol. 5 No. 4: pp. 539-560.

56. Pierson, P. (Ed.) (2001), The New Politics of the Welfare State, Oxford University Press, Oxford.

57. Potůček, M. (2008), “Metamorphoses of Welfare States in Central and Eastern Europe' in Seeleib-Kaiser, M. (Ed.), Welfare State Transformations. Comparative Perspectives, Palgrave Macmillan, New York, NY, pp. 79-95.

58. Reher, D. S. (1998), "Family ties in Western Europe: Persistent contrasts", Population and Development Review, Vol. 24 No. 2, pp. 203-234.

59. Roche, M. (1992), Rethinking Citizenship.Welfare, Ideology and Change in Modern Society, Polity Press, Cambridge, UK.

60. Roche, M (2002), “Social Citizenship: Grounds of Social Change”, in Isin, E. and Turner, B (Eds.) Handbook of Citizenship Studies, Sage, London: Sage, pp. 69-86.

61. Scharpf, F. (1996), "Negative and positive integration in the political economy of European welfare states", in Marks, G., Scharpf, F, Schmitter, P. and Streeck, W, Governance in the European Union, Sage, London, pp. 15-39.

62. Schmidt, V. (1995), "The new world order, incorporated. The rise of business and the decline of the nationstate”, Daedalus, Vol. 124 No. 2, pp. 75-106.

63. Strange, S. (1995), The Retreat of the State, Cambridge University Press, Cambridge, UK.

64. Svallfors, S. and Taylor-Gooby, P. (Eds.) (1999), The End of the Welfare State: The Responses to State Retrenchment, Routledge, London.

65. Taylor-Gooby, P. (2002), "The Silver Age of the Welfare State: Perspectives on Resilience”, Journal of Social Policy, Vol. 31 No. 4, pp. 597-621.

66. Taylor-Gooby, P. (2004), "New risks and social change", in Taylor-Gooby, P. (Ed.), New Risks, New Welfare: The Transformation of the European Welfare. Oxford: Oxford University Press.

67. Van Oorschot, W. (2002), "Popular Support for Social Security. A sociological perspective", in Clasen, J. (Ed.), What Future for Social Security? Debates and reforms in national and cross-national perspective, The Policy Press, Bristol, pp. 33-52.

68. Williams, C.C. (2007) Rethinking the Future of Work: directions and visions, Palgrave Macmillan, Basingstoke.

69. Williams, F. (2002), "The Presence of Feminism in the Future of Welfare", Economy and Society, Vol. 31 No.4, pp.502-519. 
1. Cruz Castro, L. \& Sanz MenÉndez, L. Endogamia, Productividad y Carreras Académicas.

2. Corrochano, D. Guía Bibliográfica sobre Inmigración en España (1990-2009). Datos y Reflexiones sobre la Institucionalización de una Comunidad Académica.

3. Golob, S.R. Evolution or Revolution? Transitional Justice Culture Across Borders.

4. Arias Aparicio, F. Organización y Producción del Conocimiento Científico en los Organismos Públicos de Investigación Agraria: El Instituto Nacional de Investigación Agraria y Alimentaria (INIA).

5. Moreno, L. Welfare Mix, CSR and Social Citizenship. 